Research Article

\title{
Occurrence of Enteric Viruses in Surface Water and the Relationship with Changes in Season and Physical Water Quality Dynamics
}

\author{
Wasonga Michael Opere, ${ }^{1}$ Maingi John, ${ }^{1}$ and Omwoyo Ombori ${ }^{2}{ }^{2}$ \\ ${ }^{1}$ Department of Biochemistry, Microbiology and Biotechnology, Kenyatta University, P.O. Box 43844-00100, Nairobi, Kenya \\ ${ }^{2}$ Department of Plant Sciences, Kenyatta University, P.O. Box 43844-00100, Nairobi, Kenya \\ Correspondence should be addressed to Omwoyo Ombori; richardombori@gmail.com
}

Received 14 February 2020; Revised 16 April 2020; Accepted 19 May 2020; Published 3 July 2020

Academic Editor: Finn S. Pedersen

Copyright (C) 2020 Wasonga Michael Opere et al. This is an open access article distributed under the Creative Commons Attribution License, which permits unrestricted use, distribution, and reproduction in any medium, provided the original work is properly cited.

\begin{abstract}
Environmental water quality issues have dominated global discourse and studies over the past five decades. Significant parameters of environmental water quality include changes in biological and physical parameters. Some of the biological parameters of significance include occurrence of enteric viruses. Enteric viruses can affect both human and animal's health by causing diseases such as gastrointestinal and respiratory infections. In this study, the relationship between the occurrence of enteric viruses with reference to adenoviruses and enteroviruses and the physical water quality characteristics was assessed from water samples collected from Lake Victoria (LV) in Kenya. In order to understand the dynamics of season driven enteric viruses' contamination of the lake waters, we additionally analysed seasonal behavior of the lake's catchment area in terms of rainfall effects. Physical quality parameters were measured on-site while viral analysis was carried out by molecular methods using the nested polymerase chain reaction (nPCR). From 216 samples that were analysed for viral contamination, enteric viral genomes were discovered in 18 $(8.3 \%)$ of the samples. Out of half of the samples (108) collected during the rainy season, enteric viral genomes were detected in $9.26 \%(10)$ while $8(7.41 \%)$ samples tested positive from the other half of the samples (108) collected during the dry season. There was, however, no significant correlation noted between the physical water quality characteristics and the enteric viruses' occurrence. Neither wet season nor dry season was significantly associated with the prevalence of the viruses. In Lake Victoria waters, most of the samples had an average of physical water quality parameters that were within the range accepted by the World Health Organization (WHO) for surface waters with exemption of turbidity which was above the recommended 5 NTU as recorded from some sampling sites. Continuous and long-term surveillance of the lake water to accurately monitor the contaminants and possible correlation between chemical, physical, and biological characteristics is recommended. This would be important in continuous understanding of the hydrological characteristics changes of the lake for proper management of its quality with reference to the WHO standards. A multiple varied-sampling approach in different geographical regions during different seasons is recommended to establish the geographical distribution and relatedness to seasonal distribution patterns of the viruses. The data generated from this study will be useful in providing a basis for assessment of seasonally driven fecal pollution load of the lake and enteric virus contamination for proper management of the sanitary situation around the lake.
\end{abstract}

\section{Introduction}

1.1. Background Information. Environmental water quality monitoring and research have been carried out around the world since 1970s [1, 2]. Key concern is the issue of pollution of environmental waters from point sources and surface runoffs which may eventually lead to significant public health related issues [3]. Indicators of environmental water quality include changes in biological, physical, and chemical attributes. The biological parameters that determine water quality include coliphage, coliform bacteria, and Escherichia coli $[4,5]$. The presence of these 
biological indicators however does not necessarily correspond to the occurrence of enteric viruses such as rotavirus, adenoviruses, and enteroviruses $[4,6]$. Physical quality parameters on the other hand include changes in $\mathrm{pH}$, temperature, turbidity, electrical conductivity, total dissolved solids, and dissolved oxygen [7, 8]. Some of the chemical characteristics that may be of importance include concentrations of phosphorus, silicate, nitrite, alkalinity, and heavy metals such as mercury [9]. Changes in these various categories of water quality parameters may generally lead to considerable health implications and negative impact on certain important processes for livelihood in the community such as water treatment procedures [10]. Occurrence of biological parameters may sometimes be affected by the physical quality parameters [11]. For example, occurrence of pathogenic microorganisms in surface waters can be exacerbated by higher levels of turbidity which is normally due to sewage discharge [11]. Poor quality of surface waters has also been linked to other anthropogenic activities such as agriculture, construction and mining. These activities contribute to decline of the surface water quality as they expose the waters to high sedimentation during runoffs and storm water drainage during rainy seasons [12].

Surface waters quality concerns are of great significance over the world because the surface waters are one of the main sources of drinking water after treatment [13]. In Sub-Saharan Africa, one of the key surface waters whose quality has been compromised in the recent past is Lake Victoria [14]. Lake Victoria is a fresh water lake covering about $68,800 \mathrm{~km}^{2}$ within Kenya, Uganda, and Tanzania with the Kenyan territory covering about $4,128 \mathrm{~km}^{2}$ of the total surface [14]. It has a wide catchment area served by numerous rivers and streams [15]. There has been constant increase in population, urbanization, industrialization, and agricultural activities in the recent past within the lake's catchment area [16]. This has in turn led to the contamination of the lake water with different types of pollutants such as agro-based pollutants and sewage effluents from on-site sources and off-site sources via the supplying rivers and streams [17].

As a result of pollution, the quality of the lake water is compromised, thus exposing the huge surrounding population of $1,131,950$ [18] that utilize its waters for economic, domestic, industrial, and agricultural purposes to health risks. The lake water quality ecosystem on the Kenyan side in particular has greatly deteriorated in the last five decades [14]. This deterioration has been exacerbated by eutrophication and acidification which have all been linked to anthropogenic impacts as a result of increase in population in the nearshore towns such as Kisumu, Homa Bay, and Mbita [19]. The population pressure and the activities required to support the expanding population have led to increased inflows of pollutants to the lake and to the waterways from the catchment area leading to poor quality [14]. A number of physical and chemical quality parameters on Lake Victoria (LV) were studied by Calamari et al. [20]. However, no comprehensive analysis has been undertaken to determine the relationship between the occurrence of biological parameters and the dynamics of physical-chemical parameters.
Various studies involving biological parameters on the lake have been primarily focused on coliforms [21] and planktons [22]. Enteric viruses' studies especially on the Kenyan territory have never been reported. We analysed the situation of some physical water quality parameters and the occurrence of enteric viruses with respect to adenoviruses and enteroviruses from the Kenyan side of LV waters along Homa Bay town in Kenya.

The aims of the study were therefore as follows: (1) to determine whether the physical characteristics of water in Lake Victoria along Homa Bay town influence the occurrence of the enteric viruses; (2) to determine whether the lake water physical water quality parameters are within the World Health Organization (WHO) acceptable levels for domestic use; (3) to understand the dynamics of season driven enteric viruses' contamination of surface waters through analysis of seasonal behavior of the surface waters' catchment area in terms of variation in rainfall activities. Analyses of physical water quality dynamics in relation to the enteric viral contamination in environmental waters may be useful in proper diagnosis of environmental waters quality for proper remedial action. Six physical water quality characteristics, namely, temperature, dissolved oxygen, conductivity, $\mathrm{pH}$, and turbidity, dissolved solids were analysed. For biological characteristics, enteric viruses were analysed as potential pathogens. Adenovirus (HAdV), a double-stranded DNA virus of family Adenoviridae and genus Mastadenovirus [23-25], and enteroviruses, (EV) a single-stranded positive sense RNA virus of family Picornaviridae and genus Enterovirus [26, 27], were considered as index viruses. Enteric viruses' infections are propagated by water mainly by drinking contaminated water or through contact with recreational water [28]. Enteric viruses are transmitted by fecal-oral route and can affect both human and animal's health by causing a myriad of diseases such as gastrointestinal and respiratory infections [29]. The relationship of enteric viruses' contamination of surface waters and changes in seasons is significant in recognition of the fact that fecal contamination of surface waters from the catchment area may be a result of collection and transportation of fecal contaminants in response to rainfall events [30]. The epidemiology of some enteric viruses has been reported to be affected by seasonal changes in temperate regions [31]. For example, enteroviruses have been reported to be at peaks during early autumn or late summer [32]. Studies have shown that viruses may survive relatively longer in lower temperature conditions [33]. However, adenoviruses, as one of the key waterborne enteric viruses, have been reported to exist in surface waters all year round independently on changes on season [34]. Effects of changes in seasonality on the distribution of such viruses in tropical regions such as in the sub-Saharan Africa has not been widely researched.

The study will give an insight into the present status of the quality of the lake water and provide a reference point for future monitoring of the water quality. The future monitoring will inform the design of appropriate management of pollution issues of the lake waters. Data regarding effects of changes in seasons on the contamination of surface waters with these 
viruses will be important in forming a basis for understanding of the viruses' epidemiology in the surrounding community and the potential for an outbreak. This intern would be useful in drawing of plans for control and prevention.

\section{Materials and Methods}

2.1. Study Site. The study site was located between longitudes $34.30^{\circ} \mathrm{E}$ and $34.20^{\circ} \mathrm{E}$ and latitudes $0.30^{\circ} \mathrm{S}$ and $0.35^{\circ} \mathrm{S}$ in Homa Bay Town, Homa Bay County in Western region of Kenya (Figure 1). The town is one of the major urban centres located nearshore on the Kenyan side of Lake Victoria. It is a significant station in relation to potential sources of contamination of the lake waters with pollutants such as agricultural, industrial, domestic, and sewage effluents. Its population has greatly increased in the last decade which currently stands at $1,131,950$ [18], thus compounding the pollution pressure to the surrounding lake ecosystem. The prevailing climatic condition is tropical wet with a binomial rainfall distribution pattern [35]. The longer rainy season is normally experienced from the months of March to April while the shorter rainy season is normally experienced from the months of August to November [35]. Monthly mean temperature is normally about $11.54^{\circ} \mathrm{C}$ with the annual potential range for evaporation being about $1180 \mathrm{~mm}$ to $1322 \mathrm{~mm}$ [36]. The area has gently sloping terrain surrounded by hilly topography such as Asego hill. This makes the area more vulnerable to runoffs which end up into the lake during rainy seasons.

2.2. Sampling Sites. Six points were selected from the study site for samples collection based on observed possible contamination impacts resulting from increased human activities of urbanization, including water transport, industrial and waste water treatment activities. The sampling sites were distributed along a strip in the nearshore of the lake in the town and were designated as sites S1 to S6 (Figure 2). S1 is located within decimals -0.52299 and 34.45524 and the nearby potential source of contamination identified was a landing site, water transport, and fishing activities within the surrounding. Site S2 is located within decimals -0.52201 and 34.45705 with potential source of contamination being a nearby open air market. The locations for the other sites were S3 -0.52115 and 34.45975 , S4 -0.52079 and 34.46058 , S5 -0.52001 and 34.46152 , and S6 -0.51918 and 34.46404. The observed potential sources of contaminats for these sites were; $\mathrm{S} 3$, presence of a nearby fish processing factory (Capital fish); S4, farming activities involving animal husbandry within the surrounding; S5, presence of sewage treatment works within the vicinity; and S6, being located near a residential area and a sewage treatment plant. The physical and biological parameters of the lake waters around the selected strip are suspect going by the observed levels of human activities within the surroundings.

2.3. Sample Collection. Ten litres of water samples were collected using a 10-litre sterilized clean plastic container

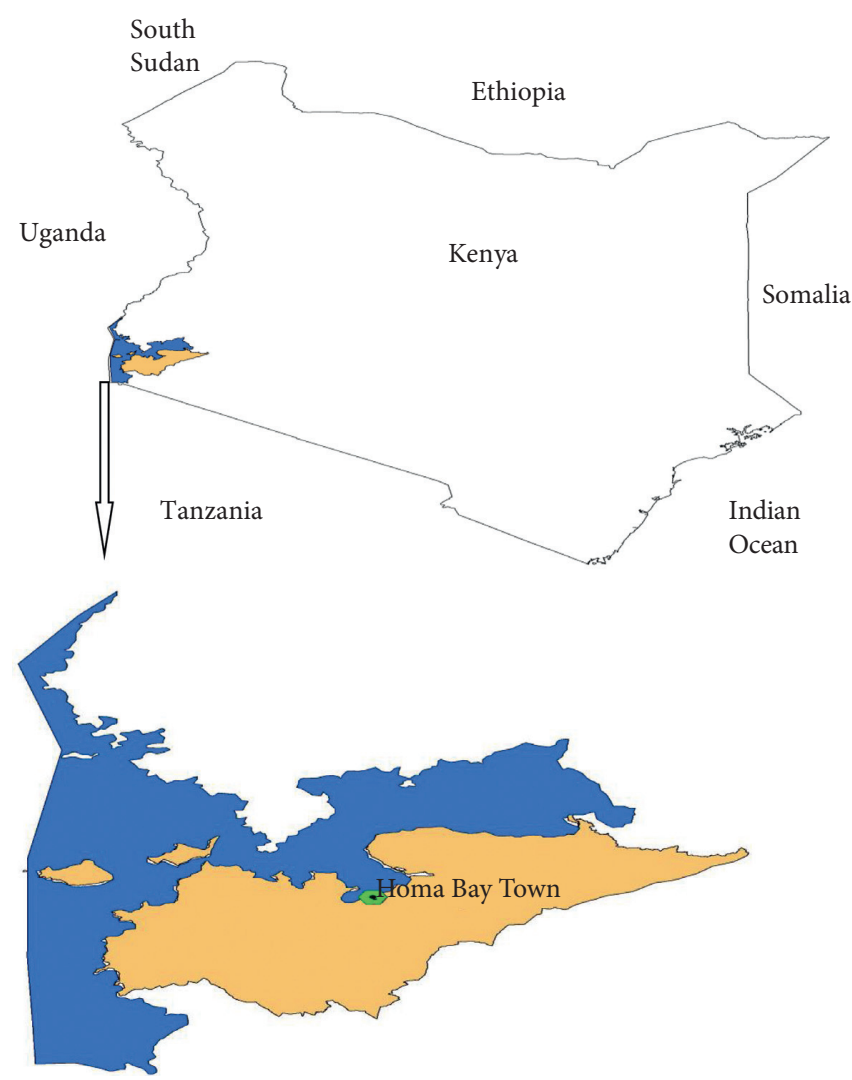

Figure 1: Map of Kenya showing Homa Bay County where the study was carried out.

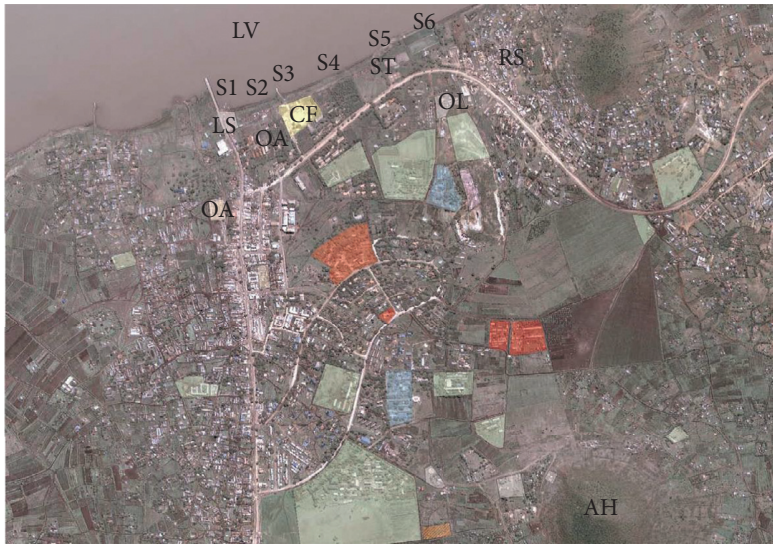

FIgURE 2: Satellite image showing the distribution of the sampling points [35]. *S: sampling sites, LS: landing site/Jetty, OA: open air market, CF: Capital fish factory, ST: sewage treatment plant, OL: old water treatment works, AH: Asego Hill, LV: Lake Victoria, and RS: residential sites.

from the surface of the water at a depth of about $50 \mathrm{~cm}$ from each of the sampling points. The sampling was carried out for a six-month period, from October 2011 to April 2012 with the period being dichotomised as rainy or dry season. Sampling months of October 2011, November 2011, and April 2012 were rainy months, while January, February, and March 2012 were all dry months. December 2012 was not included as a sampling month so as to balance the number of 
sampling trips for the wet/dry season dichotomy. The number of samples per every sampling trip/month from a single site was 6 , making a total of 36 samples across all the six sampling sites per trip and 216 for the entire six-month sampling period. The total sampling volume per site was 60 litres, making a total volume of 2160 litres for the entire sampling period. According to a joint report from the Food and Agriculture Organization (FAO) of the United Nations and the Kenya Food Security Steering Group (KFSSG) from 2011 to 2012 when the sampling was carried out, the highest recording of rainfall was in April 2012 with the maxim recording being about $165 \mathrm{~mm}$. On the other hand, the lowest rainfall amount was recorded in January 2012 which was only about $10 \mathrm{~mm}$ (Figure 3).

2.4. Measuring of Physical Quality Parameters. The physical quality parameters were measured and recorded in situ in the field during sample collection according to the Standard Methods for the Examination of Water and Wastewater-the $21^{\text {st }}$ edition as described by the American Public Health Association [37]. Briefly, various portable water probe equipment were used to get the measurements on-site. Temperature and $\mathrm{pH}$ were measured by the electrode probe method using water temperature and $\mathrm{pH}$ meter model (Jenway, model 550). Dissolved oxygen was also analysed by an electrode method using a multimeter electrochemical analyser (Jenway, model 3405). Turbidity was analysed by the turbidimetric method using a portable turbidimeter (turbidimeter-model 2100 USA) while electrical conductivity and total dissolved solids were measured using a total dissolved solids/conductivity meter (Jenway model 4076).

2.5. Detection of Enteric Viral Genome from the Samples. Once the physical characteristics were recorded on-site, the samples were transported on ice to the Enteric Viruses Research Group-Institute of Primate Research Laboratory in Nairobi, Kenya, for enteric viruses' analysis where they were temporarily stored at a temperature of $4^{\circ} \mathrm{C}$ until processing [38]. Sample processing was done between 6 and 8 hours following collection process. Concentration of the samples and recovery of the virus were carried out using glass wool adsorption-elution technique according to the methods originally described by Vilaginès et al. [39] and subsequently modified by Wolfaardt et al. [40], Lambertini et al. [41], and Miagostovich [42]. Briefly, the process involved filtering and draining of 10 litres of the water samples through a column of a Perspex glass tube stocked with layers of positively charged oiled sodocalcic glass wool filters. The draining of the water from the glass tubes was achieved by application of a negative pressure using a vacuum pump. A few samples that had $\mathrm{pH}$ greater than 7.00 were normalised using $1 \mathrm{~N} \mathrm{HCl}$ to adjust their $\mathrm{pH}$ to 7.00 before the filtration process to enhance adsorption of the viruses during the sample concentration process [43].

Being that virus particles are negatively charged, the viruses got adsorbed to the positively charged glass wool filters during the running of the sample through the perspex column [41]. The adsorbed viruses were eluted from the glass

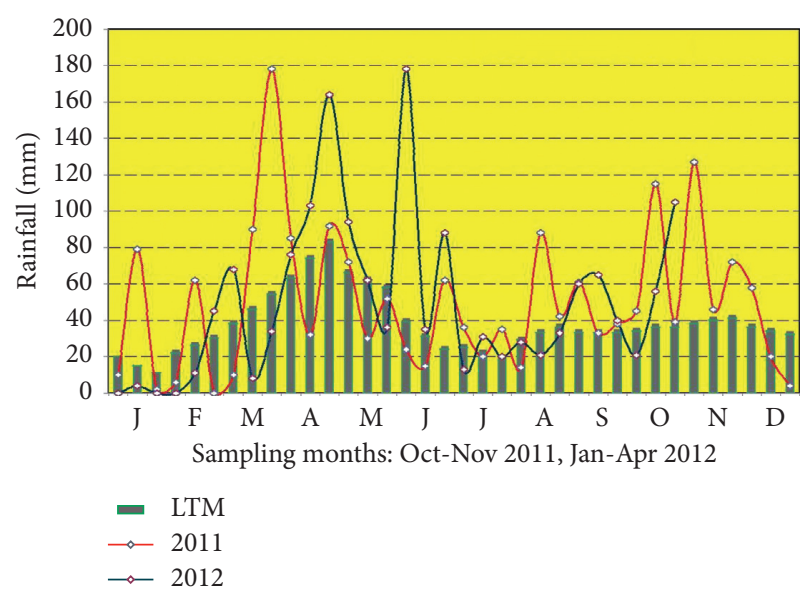

Figure 3: 2012 rainfall distributions, Homa Bay, Nyanza. Source: FAO and KFSSG [36]. LTM: last twelve months.

wool filters using $100 \mathrm{ml}$ of glycine-beef extract buffer (GBEB), $\mathrm{pH}$ 9.5. One hundred millilitres of the elute was subjected to secondary concentration by washing using polyethylene glycol/sodium chloride ( $\mathrm{PEG} / \mathrm{NaCl}$ ) according to the methods previously described by Vilaginès et al. [44]. The resultant solution of the secondary concentration was incubated overnight at $4^{\circ} \mathrm{C}$ and then centrifuged at $4,200 \mathrm{rpm}$ for $45 \mathrm{~min}$ at $4{ }^{\circ} \mathrm{C}$. The resulting pellets were resuspended in a $2 \mathrm{ml}$ of sterile phosphate-buffered saline

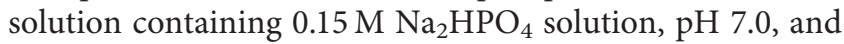
later centrifuged at $3000 \mathrm{rpm}$ for $10 \mathrm{~min}$ at $4^{\circ} \mathrm{C}$. The supernatant was collected into a sterile container [38] and stored in separate sterile $20 \mathrm{ml}$ glass tubes (Thermo Fisher Scientific) at a temperature of $-70^{\circ} \mathrm{C}$ [45] until use for nucleic acid extractions. The virus concentrates were stored for between 2 and 12 hours before nucleic acid extraction in which $2 \mathrm{ml}$ of the supernatant was later used for the process.

Nucleic acids were extracted from the $2 \mathrm{ml}$ supernatant using the automated commercially available extratcion kits. The MagNA pure total nucleic acid extraction kit (Roche Diagnostics) and RNeasy minikit (QIAGEN) were used for extraction of the DNA and RNA extratcion respectively, according to the manufacturer's instructions. The DNA extracts were stored in Tris-EDTA ( $\mathrm{pH}$ 8.0) at a temperature of $-20^{\circ} \mathrm{C}$ until use following an elution process. The RNA extracts on the other hand were stored by freezing in RNase free water at $-80^{\circ} \mathrm{C}$. From $2 \mathrm{ml}$ of the extracted nucleic acids solutions, nested PCR was used for amplification according to methods described by $[46,47]$ with minimal modifications. For the RNA genome, reverse transcription (RT) was first carried to synthesis $\mathrm{m}$ cDNA for enteroviruses before the PCR process. Published primers as previously described in studies of Allard et al. [48], Allard et al. [34], and Allard et al. [46] and further described by Santos et al. [49] were used for the PCR process. The PCR products were visualised using 2\% agarose gel electrophoresis stained with ethidium bromide. During the handling of the samples in the laboratories, care was taken to minimise chances of cross contamination. Some of the precautions adopted include carrying out samples processing in different laboratories 
with different set of apparatus. Probability of amplifying contaminant DNA was reduced by treating the nucleic acid samples with uracil DNA glycosylase [50].

2.6. Data Analysis. Two-way analysis of variance (ANOVA) test was used to analyse comparison of the variations between the physical parameters at different seasons and the sampling sites, while Pearson correlation was used to analyse the relationship between the physical parameters and viruses' presence. SAS version 9.1(SAS Inst. INC., Car., NC) was used to carry out all the analyses in which the $p$ values were considered statistically significant at $p$ values $<0.05$.

\section{Results}

3.1. Occurrence of the Enteric Viruses. From a total of 216 samples that were collected for viral analysis, the enteric viral genomes were detected in $18(8.3 \%)$ of them. Of these 18 positive samples, 8 (44.4\%) were recorded from site S5, while $5(27.78 \%)$ were from site S6 apparently suggesting higher pollution levels in the surrounding areas. Sites S1, S2, and S4 recorded 1 viral genome each, jointly accounting for only $16.67 \%$ of the total number of positive samples while site S3 had two $(11.11 \%)$ positive samples (Table 1$)$.

As regards to seasonal distribution of the viruses, the genomes were detected at least once in each of the six sites sampled during the two seasons, although no site was viruspositive in every sampling month (Table 2). Out of 108 samples collected between October and November and in April which were rainy months, 10 (9.26\%) had enteric virus genomes. Similarly, out of the 108 samples collected from January to March during the dry season, 8 (7.41\%) tested positive for adenovirus and enteroviruses contamination (Table 2).

As regards relationship between microbiological parameters in question (human adenoviruses and enteroviruses) and the seasons of samples collection, we observed that there was no significant difference in the number of adenovirus detection during the dry and wet season $(p=0.7440)$ (Table 3$)$. The highest mean for the number of adenovirus genome detected although was observed during the wet season (0.06) in comparison to the dry season (0.05) (Table 3). Similarly, enteroviruses detection was not significantly different between the wet and dry seasons $(p=0.7010)$. The highest mean for enteroviruses however was observed during the wet season (0.04) while the mean detection for the dry season was (0.03).

3.2. Physical Quality Characteristics. The result of the six physical water quality characteristics was analysed between the wet and the dry seasons and among the six sampling sites in relation to the World Health Organization (WHO) standards for environmental waters. Generally, the average values for most of all the physical parameters were found to be in compliance with WHO acceptable levels except in few cases (Table 3). For example, the results show that most of the samples had $\mathrm{pH}$ average values ranging from 7.00 to 7.06 which were within the WHO acceptable levels of 6.50-8.00.
TABLE 1: Summary of the bivariate analysis for the viral contamination by site.

\begin{tabular}{lccccc}
\hline \multirow{2}{*}{$\begin{array}{l}\text { Sampling } \\
\text { sites }\end{array}$} & $\begin{array}{c}\text { No. of } \\
\text { samples }(n)\end{array}$ & \multicolumn{4}{c}{ Contamination } \\
& & Virus absent & \multicolumn{2}{c}{ Virus present } \\
\hline S1 & 36 & 35 & 97.22 & 1 & 2.78 \\
S2 & 36 & 35 & 97.22 & 1 & 2.78 \\
S3 & 36 & 34 & 94.44 & 2 & 5.56 \\
S4 & 36 & 35 & 97.22 & 1 & 2.78 \\
S5 & 36 & 28 & 77.78 & 8 & 22.22 \\
S6 & 36 & 31 & 86.11 & 5 & 13.89 \\
\hline
\end{tabular}

Similarly, the mean temperature values varied between $25.47^{\circ} \mathrm{C}$ and $25.92^{\circ} \mathrm{C}$ for all the sampling periods as measured on-site. The results indicate that the water temperature was within the acceptable limits of $\pm 2^{\circ} \mathrm{C}$ from $25.00^{\circ} \mathrm{C}$. All conductivity and TDS samples were however below the thresholds recommended by the WHO at $500-5000 \mathrm{mS} / \mathrm{cm}$ and $1000 \mathrm{mg} / \mathrm{l}$, respectively, for fresh water bodies. Higher levels of dissolved oxygen were recorded from sites S1 and S2 which are characterized by slightly intense anthropogenic activities. Average DO values at these two sites were $9.55 \mathrm{mg} /$ 1 and S2, $9.46 \mathrm{mg} / \mathrm{l}$, which is above the WHO recommended values of $8-9 \mathrm{mg} / \mathrm{l}$. On the other hand, lower DO values than the recommended range were recorded from site S6, with mean DO levels from the site being $7.98 \mathrm{mg} / \mathrm{l}$. It is noteworthy that this site is located close to a residential place and not so distant from a sewage treatment plant; the possibility of its samples being highly contaminated is real from possible domestic discharge and sewage leaks. Majority of the samples nonetheless recorded DO levels which were within the WHO recommended range. As for turbidity values, all the average values in the various sites and seasons were found to be above the recommended values in comparison to the WHO guidlines for environmental waters of 5 NTU (Table 3).

Analysis of these parameters between the two seasons and among the different sampling sites revealed that there were generally significant differences with the probability values being $p \leq 0.5$. For instance, seasonal analysis of electrical conductivity indicates that there was a significant difference $(p \leq 0.5, p=0.0001)$ during the dry and wet seasons. Significant difference was also noted in changes on values between the sites $(p=0.0001)$ (Table 3$)$. In terms of recorded values between the wet and the dry seasons, the highest mean conductivity was observed during the dry season $(70.73 \mu \mathrm{S} / \mathrm{cm})$ while the lowest mean conductivity was observed in dry season $(0.28 \mu \mathrm{S} / \mathrm{cm})$ (Table 3$)$. On the other hand, conductivity values per site indicate that the highest mean conductivity was observed in site S2 $(60.02 \mu \mathrm{S} /$ $\mathrm{cm}$ ) while the lowest mean conductivity was observed in site S5 at $3.91 \mu \mathrm{S} / \mathrm{cm}$ (Table 3 ). Similarly, difference in turbidity levels was strongly significant between the seasons as well as the sites $(p=0.0001)$. The highest mean value in terms of season was 19.73 NTU during the wet season while in terms of sites, it was in site S5, being 21.50 NTU.

We evaluated the relationship of the occurrence of the two microbial parameters (HAdV and $\mathrm{EV}$ ) in the water 
TABLE 2: Summary of virus detection from each site during the wet and the dry seasons.

\begin{tabular}{|c|c|c|c|c|c|c|c|c|}
\hline Month & Season & Enteric virus & $\mathrm{L} 1$ & $\mathrm{~L} 2$ & L3 & L4 & L5 & L6 \\
\hline \multirow[t]{2}{*}{ October 2011} & Wet & Enterovirus & 0 & 0 & 0 & 0 & 0 & 0 \\
\hline & & Adenovirus & 0 & 0 & 0 & 0 & $1 / 11$ & 0 \\
\hline \multirow[t]{2}{*}{ November 2011} & Wet & Enterovirus & 0 & 0 & 0 & 0 & $2 / 7$ & 0 \\
\hline & & Adenovirus & $1 / 11$ & 0 & 0 & 0 & $2 / 11$ & 0 \\
\hline \multirow[t]{2}{*}{ January 2012} & Dry & Enterovirus & 0 & 0 & 0 & 0 & $1 / 7$ & 0 \\
\hline & & Adenovirus & 0 & 0 & $2 / 11$ & 0 & 0 & 0 \\
\hline \multirow[t]{2}{*}{ February 2012} & Dry & Enterovirus & 0 & 0 & 0 & $1 / 7$ & 0 & 0 \\
\hline & & Adenovirus & 0 & 0 & 0 & 0 & 0 & $2 / 11$ \\
\hline \multirow[t]{2}{*}{ March 2012} & Dry & Enterovirus & 0 & $1 / 7$ & 0 & 0 & 0 & 0 \\
\hline & & Adenovirus & 0 & 0 & 0 & 0 & 0 & $1 / 11$ \\
\hline \multirow[t]{2}{*}{ April 2012} & Wet & Enterovirus & 0 & 0 & 0 & 0 & 0 & $2 / 7$ \\
\hline & & Adenovirus & 0 & 0 & 0 & 0 & $2 / 11$ & 0 \\
\hline
\end{tabular}

The numerator represents the number of viruses detected in a given month, while the denominator represents the total number of the specific virus detected during the whole period. Zeroes represent nondetection.

TABle 3: Two-way analysis of variance with post hoc analysis using Tukey's HSD on physical parameters and viruses present.

\begin{tabular}{|c|c|c|c|c|c|c|c|c|}
\hline Treatment & $\mathrm{pH}$ & Temp. $\left({ }^{\circ} \mathrm{C}\right)$ & $\mathrm{EC}(\mu \mathrm{S} / \mathrm{cm})$ & TDS (mg/l) & $\mathrm{DO}(\mathrm{mg} / \mathrm{l})$ & $\begin{array}{c}\text { Turbidity } \\
\text { (NTU) }\end{array}$ & $\begin{array}{c}\text { HAdV } \\
\text { detected }\end{array}$ & $\begin{array}{c}\mathrm{EV} \\
\text { detected }\end{array}$ \\
\hline \multicolumn{9}{|l|}{ Season } \\
\hline Dry & $7.00 \pm 0.00 a^{*}$ & $25.90 \pm 0.03 a$ & $70.73 \pm 3.89 a$ & $50.14 \pm 3.24 a$ & $8.81 \pm 0.12 \mathrm{a}$ & $9.98 \pm 0.25 a$ & $0.05 \pm 0.02 \mathrm{a}$ & $0.03 \pm 0.02 \mathrm{a}$ \\
\hline Wet & $7.03 \pm 0.011072 b$ & $25.56 \pm 0.07 \mathrm{a}$ & $0.28 \pm 0.05 b$ & $47.56 \pm 2.08 \mathrm{~b}$ & $8.58 \pm 0.11 b$ & $19.73 \pm 0.85 b$ & $0.056 \pm 0.02 \mathrm{a}$ & $0.04 \pm 0.02 \mathrm{a}$ \\
\hline \multicolumn{9}{|l|}{ Site } \\
\hline S1 & $7.00 \pm 0.0 \mathrm{~b}$ & $25.47 \pm 0.13 c$ & $56.97 \pm 11.40 \mathrm{a}$ & $87.17 \pm 6.13 a$ & $9.55 \pm 0.20 \mathrm{a}$ & $6.06 \pm 0.25 \mathrm{e}$ & $0.03 \pm 0.03 a$ & $0.03 \pm 0.03 \mathrm{a}$ \\
\hline S2 & $7.00 \pm 0.00 \mathrm{~b}$ & $25.78 \pm 0.07 \mathrm{abc}$ & $60.02 \pm 10.14 \mathrm{a}$ & $30.58 \pm 1.66 c$ & $9.46 \pm 0.24 \mathrm{a}$ & $16.00 \pm 1.05 c$ & $0.00 \pm 0.00 \mathrm{~b}$ & $0.03 \pm 0.03 \mathrm{a}$ \\
\hline S3 & $7.00 \pm 0.00 \mathrm{~b}$ & $25.83 \pm 0.06 \mathrm{ba}$ & $34.63 \pm 5.90 \mathrm{~b}$ & $50.72 \pm 1.58 b$ & $8.46 \pm 0.17 b c$ & $11.00 \pm 0.40 \mathrm{~d}$ & $0.06 \pm 0.04 \mathrm{a}$ & $0.00 \pm 0.00 \mathrm{a}$ \\
\hline S4 & $7.00 \pm 0.00 b$ & $25.53 \pm 0.13 b c$ & $20.62 \pm 3.38 c$ & $25.47 \pm 0.78 d$ & $8.63 \pm 0.15 b$ & $15.50 \pm 1.11 \mathrm{c}$ & $0.00 \pm 0.00 \mathrm{~b}$ & $0.00 \pm 0.00 \mathrm{a}$ \\
\hline S5 & $7.06 \pm 0.03 a$ & $25.83 \pm 0.06 \mathrm{ab}$ & $3.91 \pm 0.00 c$ & $50.00 \pm 3.66 b$ & $8.08 \pm 0.11 b c$ & $21.50 \pm 1.56 \mathrm{a}$ & $0.14 \pm 0.06 a$ & $0.08 \pm 0.05 \mathrm{a}$ \\
\hline S6 & $7.03 \pm 0.02 \mathrm{ab}$ & $25.92 \pm 0.05 a$ & $4.25 \pm 0.00 c$ & $49.17 \pm 3.52 b$ & $7.98 \pm 0.10 c$ & $19.08 \pm 1.34 b$ & $0.08 \pm 0.05 a$ & $0.06 \pm 0.04 \mathrm{a}$ \\
\hline $\begin{array}{l}\text { WHO } \\
\text { standards } \\
P \text { values } \\
\end{array}$ & $6.5-8.5$ & $25^{\circ} \mathrm{C} \pm 2$ & $500-5000$ & 500-1000 & $8-9$ & $<5$ & & \\
\hline Season & 0.0090 & $<0.0001$ & ( & & & $<.0001$ & & 0.7010 \\
\hline Site & 0.0077 & 0.0002 & $<0.0001$ & $<0.0001$ & 0.0447 & $<.0001$ & 0.0373 & 0.3046 \\
\hline
\end{tabular}

*Values followed by the same letter along the column are not significantly different based on Tukey's HSD at $p \leq 0.5$. EC: electrical conductivity, TDS: total dissolved solids, and DO: dissolved oxygen.

TABLE 4: Correlation of physical parameters and viruses present.

\begin{tabular}{|c|c|c|c|c|c|c|c|c|}
\hline & $\mathrm{pH}$ & Temp. $\left({ }^{\circ} \mathrm{C}\right)$ & EC & TDS & DO & Turbidity & HAdV detection & EV detection \\
\hline \multirow[t]{2}{*}{ Temp. $\left({ }^{\circ} \mathrm{C}\right)$} & ${ }^{*} 0.032$ & & & & & & & \\
\hline & 0.636 & & & & & & & \\
\hline \multirow[t]{2}{*}{$\mathrm{EC}$} & -0.131 & 0.267 & & & & & & \\
\hline & 0.055 & 0.0001 & & & & & & \\
\hline \multirow[t]{2}{*}{ TDS } & 0.125 & 0.147 & 0.331 & & & & & \\
\hline & 0.067 & 0.031 & 0.0001 & & & & & \\
\hline \multirow{2}{*}{ DO } & -0.108 & 0.012 & 0.245 & 0.214 & & & & \\
\hline & 0.115 & 0.850 & 0.0001 & 0.002 & & & & \\
\hline \multirow[t]{2}{*}{ Turbidity } & 0.247 & 0.011 & -0.542 & -0.132 & -0.157 & & & \\
\hline & 0.0001 & 0.874 & 0.0001 & 0.053 & 0.021 & & & \\
\hline \multirow[t]{2}{*}{ HAdV detection } & 0.089 & 0.114 & -0.062 & 0.045 & -0.083 & 0.108 & & \\
\hline & 0.193 & 0.096 & 0.366 & 0.508 & 0.222 & 0.113 & & \\
\hline \multirow{2}{*}{ EV detection } & 0.128 & 0.090 & -0.027 & 0.119 & -0.068 & 0.087 & -0.042 & \\
\hline & 0.060 & 0.188 & 0.693 & 0.082 & 0.317 & 0.202 & 0.535 & \\
\hline
\end{tabular}

${ }^{*}$ Cell contents: Pearson correlation $(r)$; $p$ value at 0.05 probability level. Temp: temperature, EC: electrical conductivity, TDS: total dissolved solids, DO: dissolved oxygen, HAdV: human adenovirus, and EV: enteroviruses. 
samples and the six physical water quality dynamics (temperature, electrical conductivity, total dissolved solids, dissolved oxygen, $\mathrm{pH}$, and turbidity). The occurrence of the viruses did not show any significant relationship with any of the physical parameters (Table 4). However, there were significant associations between the physical parameters themselves. For example, there was a strong positive correlation between TDS and EC $(r=0.331, p=0.0001)$ and a strong negative correlation between turbidity and EC $r=-0.542, p=0.0001)$.

\section{Discussion}

4.1. Occurrence of the Viruses from the Water Samples. Enteric viruses such as HAdV and EVs have been discovered in many of surface waters around the world [51-53]. In this study, the genomes of these viruses were discovered in $8.3 \%$ of the 216 samples analysed. This corroborates with other findings that have been reported around the world from different studies as regards the occurrence of enteric viruses in surface waters [54]. Based on the analysis of seasonal viral occurrences, we observed that virus detections varied through the sampling months that included both the wet and the dry seasons from individual sampling sites. Rainfall activities may lead to increase in the level of contamination of the surface waters by enteric viruses as a result of occasional discharges from surface runoffs [30]. During the sampling period, it was observed that there was higher rainfall activity in the month of October 2011, and thus, the lake received a lot of runoff water in this first month of sampling. However, the analysis show that there was neither a significant higher detection nor increase in the number of viruses detected in the following month of November which was also a wet season. In general, the detection of the viruses in this study did not show any significant change during the flooding heavy rainfall months of October 2011, November 2011, and April 2012 and the three dry months. These results nonetheless are consistent with a past study reported in SubSaharan Africa by Ayukekbong et al. [31] in Cameroon and elsewhere [55-57]. Other studies although have revealed seasonal effects on detection of other types of enteric virus in certain environmental waters. For example, human caliciviruses have been found to be more prevalent during the colder months of the year [58]. Adenoviruses and enteroviruses have also been reported to show relatively little change in concentration with changes in seasonal trends throughout the year [59].

Studies have found that virus can persist suspended in environmental waters for several days at both very low and high temperatures [5]. It has been reported from past studies that viral persistence in the environmental waters increases with decrease in temperature [60]. This means that viruses are likely to persist more if the lake is cooler than when warm [61]. According to the results, there was no significant difference in variation in temperature recorded during both the wet and the dry seasons and this could be one of the reasons as to why there was no significant difference in the detection of viruses in both dry and rainy seasons. Viruses have been isolated throughout the year with slight increase in concentration during rainy seasons although not always $[60,62]$. Despite the fact that there was no significant change in detection during wet seasons, it can be assumed that viruses may have been transported to the sampling sites later after getting desorbed from subsurface sediments after infiltration of rainfall and hence can be detected at a later date [57].

Studies have shown that there are chances of increase in ease of transportation of viruses with increase in water flow and this may increase chances of viral detection [63]. However, few viruses were detected during increased water flow period in the wet months and a possible explanation for this could be the dilution effect of the flooding activities [56]. During dry seasons, less water flow happens but contamination of the lake water by the viruses can still occur through aquifer pathways [64]. This could explain the near similar detection of the viruses during the dry season. Virus detection during dry season however is not affected by the dilution effect due to less water flow [65]. Contamination during the dry season can be through the ground flow probably exacerbated by the positive surface waters which is in contrast with the wet season when contamination is likely to be through water flow in the upper part of the soil [29].

Higher detection of viruses from some of the sites such as sites S5 and S6 could be an indication to high level of contamination or discharge of pollutants around the sites. This could be attributed to intense human activities from pressure of urbanization leading to sewage and industrial and agricultural discharges to the lake. Lower detection from sites S1, S2, and S3 could as well be associated with factors that may have hindered PCR detection of the viruses. Certain conditions and chemicals have been reported to limit PCR amplification [66]. Some of these factors include waters with high concentration of humus, phenols, and heavy metals [67].

4.2. Physical Quality Characteristics. Most of the samples from all the sites recorded physical water quality characteristics that were within the recommended range of values according to the World Health Organization except for turbidity which was higher in most of the samples. The higher levels of turbidity however could be attributed to agricultural activities from the surrounding community especially during the rainy seasons as a result of runoff carrying silt [8]. The mean average temperature of the samples was $25^{\circ} \mathrm{C}$ with a range of $24^{\circ} \mathrm{C}$ to $26^{\circ} \mathrm{C}$ which falls within the recommended temperature ranges for inland waters and suitable for aquatic life which does not thrive well when the temperature changes by a $\pm 2^{\circ} \mathrm{C}[68,69]$. There were high concentrations of dissolved oxygen recorded in some cases although a larger percentage fell within the WHO recommended range of $8-9 \mathrm{mg} / \mathrm{l}$ for surface water. A DO below $5 \mathrm{mg} / \mathrm{l}$ signifies a highly polluted water and not suitable for aquatic life and may act as an indicator for poor water quality [70]. There was a variation of results of DO with a mean range of 7.98-10.40 $5 \mathrm{mg} / \mathrm{l}$ recorded across the two seasons indicating presence of limited organic waste in the lake. Samples from site S6 recorded slightly lower value 
than the recommended range, with mean DO levels of $7.98 \mathrm{mg} / \mathrm{l}$. This lower value could be attributed to increased discharge of untreated industrial and urban wastewater [71].

\subsection{Analysis of the Relationship between Physical Parameters} and Biological Parameters. Relationship between physical water quality parameters and viral contamination in surface waters has been reported in previous studies [72]. Positive correlation has been reported between some physical parameters such as turbidly and $\mathrm{PH}$ with enteric viruses' presence in surface waters [73]. Higher turbidity in particular has been reported to contribute to difficulty in executing various water purification processes such as flocculation and filtration, thereby increasing the cost of water treatment and consequently may lead to increased chances of fecal pollution and enteric viruses' contamination [62]. We conducted a longitudinal monitoring for 6 months, in which two microbiological parameters (adenoviruses and enteroviruses) situation and the relationship with physical quality parameters ( $\mathrm{pH}$, temperature, turbidity, dissolved oxygen, electrical conductivity, and total dissolved solids) were assessed. Generally, there was no significant correlation observed between the microbiological and physical parameters. However, among the 6 physical parameters evaluated and correlated with the microbiological parameters, turbidity was the only one found to be significantly above the recommended level by the WHO. However, this does not seem to have had an effect on its correlation with the biological parameters. This result is consistent with previous studies where no correlation was recorded between the occurrence of viruses and the changes of physical quality parameters. For example, Lee et al. [74] reviewed and documented absence of correlation between biological and physical parameters. The occurrence of viruses in water for example did not correlate with physical factors such as $\mathrm{pH}$ and turbidity. Similar reports by Lee et al. [74] have reported lack of correlation between enteroviruses presence in surface waters with physical parameters such as turbidity and temperature of the waters.

\section{Conclusions}

Most of the samples had an average of the physical water quality parameters that were within the range accepted by the WHO. However, the detection of turbidity above the levels recommended by the WHO and DO concentrations in some cases at levels below the recommended threshold is a justification that the level of pollution of the lake water is high and therefore the lake environment should be subjected to continuous monitoring for proper management of pollution challenges. Adenoviruses and enteroviruses occurrence in LV waters are relatively constant throughout the year without significant variations in their profile with changes in season. Changes in season dynamics may therefore be considered to be an unreliable factor for prediction of viral contamination peaks in the lake.

In addition to these findings, the physical and microbiological parameters were found not to be significantly correlated; the occurrence of the viruses was not affected by changes in the physical parameters. We recommend a more detailed continuous long-term surveillance of the lake waters to accurately monitor the contaminants and possible correlation between chemical parameters and other physical characteristics not covered in this study such as light penetration and the virus occurrence. There was no significant influence of season in detection of the viruses as per the present study; however, a multisampling approach in different regions and during different seasons is recommended to establish the viruses' geographical distribution and relatedness to seasonal distribution patterns.

\section{Data Availability}

The metadata used to support the findings of this study have been deposited in the Kenyatta University Institutional repository at http://ir-library.ku.ac.ke/handle/123456789/ 19905.

\section{Conflicts of Interest}

The authors declare that they have no conflicts of interest.

\section{Authors' Contributions}

WMO designed the study, carried out fieldwork, performed the experiments and the statistical data analysis, and wrote the first draft of the manuscript. MJ and OO managed the literature searches and analyses of the study. All the authors have read and approved the final manuscript.

\section{Acknowledgments}

The authors acknowledge a postgraduate bursary from Karachuonyo Constituency Development Fund for research. The authors acknowledge Mr. Nicholas Kiulia of the Institute of Primate Research in Kenya for many fruitful discussion and guidance during the whole period of the project. The authors thank the entire staff of the Institute of Primate Research and the National Museum of Kenya for providing laboratory space. The authors also like to thank Maxwell Adek for his assistance in field sampling.

\section{References}

[1] H. A. Hawkes, "Origin and development of the biological monitoring working party score system," Water Research, vol. 32, no. 3, pp. 964-968, 1998.

[2] S. M. Mohammed, "A review of water quality and pollution studies in Tanzania," AMBIO: A Journal of the Human Environment, vol. 31, no. 7, pp. 617-620, 2002.

[3] M. Wong, L. Kumar, T. M. Jenkins, I. Xagoraraki, M. S. Phanikumar, and J. B. Rose, "Evaluation of public health risks at recreational beaches in Lake Michigan via detection of enteric viruses and a human-specific bacteriological marker," Water Research, vol. 43, no. 4, pp. 1137-1149, 2009.

[4] J. Lin and A. Ganesh, "Water quality indicators: bacteria, coliphages, enteric viruses," International Journal of Environmental Health Research, vol. 23, no. 6, pp. 484-506, 2013. 
[5] A. D. Vecchia, C. Rigotto, R. Staggemeier, M. C. Soliman, F. G. de Souza, and A. Henzel, "Surface water quality in the Sinos River basin, in Southern Brazil: tracking microbiological contamination and correlation with physicochemical parameters," Environ Sci Pollut Res, vol. 22, pp. 9899-9911, 2015.

[6] J. M. Colford, T. J. Wade, K. C. Schiff et al., "Water quality indicators and the risk of illness at beaches with nonpoint sources of fecal contamination," Epidemiology, vol. 18, no. 1, pp. 27-35, 2007.

[7] R. E. Hecky, "The eutrophication of Lake Victoria," SIL Proceedings, 1922-2010 Sturtgart, vol. 25, no. 1, pp. 39-48, 1993.

[8] A. F. M. Alkarkhi, A. Ahmad, and A. M. Easa, "Assessment of surface water quality of selected estuaries of Malaysia: multivariate statistical techniques," The Environmentalist, vol. 29, no. 3, pp. 255-262, 2009.

[9] K. Onda, J. LoBuglio, and J. Bartram, "Global access to safe water: accounting for water quality and the resulting impact on MDG progress," International Journal of Environmental Research and Public Health, vol. 9, no. 3, pp. 880-894, 2012.

[10] T. J. Wade, E. Sams, K. P. Brenner et al., "Rapidly measured indicators of water quality and swimming associated illnesses at marine beaches: a prospective cohort study," Environmental Health, vol. 9, pp. 1-14, 2010.

[11] S. M. McQuaig, T. M. Scott, J. O. Lukasik, J. H. Paul, and V. J. Harwood, "Quantification of human polyomaviruses JC Virus and BK Virus by TaqMan quantitative PCR and comparison to other water quality indicators in water and fecal samples," Applied and Environmental Microbiology, vol. 75, no. 11, pp. 3379-3388, 2009.

[12] EPA, National Management Measures to Control Nonpoint Source Pollution from Urban Areas, U.S. Environmental Protection Agency, Washington, DC, USA, Document No. EPA 841-B-05-004, 2005.

[13] K. E. Gibson and K. J. Schwab, "Detection of bacterial indicators and human and bovine enteric viruses in surface water and groundwater sources potentially impacted by animal and human wastes in lower Yakima valley, Washington," Applied and Environmental Microbiology, vol. 77, no. 1, pp. 355-362, 2011.

[14] P. M. Mwirigi, P. Gikuma-Njuru, J. O. Okungu, J. O. Z. Abuodha, and R. E. Hecky, "Lake Victoria monitoring of the pelagic, littoral, river mouths and near shore urban environments, Kenya," Kenya National Water Quality Synthesis Report, Lake Victoria Environment Management project (LVEMP), Kisumu, Kanya, 2005.

[15] N. J. Baker and E. Eric, "Integrating wildlife in natural resources management for tourism and community livelihoods in Lake Victoria basin: East Africa," African Journal of Environmental Science Technology, vol. 2, pp. 287-295, 2008.

[16] C. Kessides, The Urban Transition in Sub-Saharan Africa: Implications for Economic Growth and Poverty Reduction, Cities Alliances, Washington DC, USA, 2006.

[17] S. Singh, "Investigation of bacterial fecal indicators and coliphage virus in sediment and surface water of parks and beaches along the Grand River (MI) and Lake Michigan (MI)," Master's thesis, Michigan State University, East Lansing, MI, USA, 2007.

[18] KNBS, 2019 Kenya Population and Housing Census: Volume 1 A Population Distribution by Administrative Units, Kenya National Bureau of Statistics, Ministry of Planning \& National Development, Kenya, Nairobi, 2019.

[19] J. Onyuka, R. Kakai, D. Onyango, P. Arama, J. Gichuki, and O. Ofulla, "Prevalence and antimicrobial susceptibility patterns of enteric bacteria isolated from water and fish in Lake Victoria basin of Western Kenya," World Academy of Science, Engineering and Technology, vol. 75, pp. 1320-1350, 2011.

[20] D. Calamari, M. O. Akech, and P. B. O. Ochumba, "Pollution of Winam Gulf, Lake Victoria, Kenya: a case study for preliminary risk assessment," Lakes and Reservoirs: Research and Management, vol. 1, no. 2, pp. 89-106, 1995.

[21] D. Byamukama, F. Kansiime, R. L. Mach, and A. H. Farnleitner, "Determination of Escherichia coli contamination with chromocult coliform agar showed a high level of discrimination efficiency for differing fecal pollution levels in tropical waters of Kampala, Uganda," Applied and Environmental Microbiology, vol. 66, pp. 864-868, 2005.

[22] K. M. Mavuti and M. R. Litterick, "Composition, distribution and ecological role of zooplankton community in Lake Victoria, Kenya waters," SIL Proceedings, 1922-2010, vol. 24, no. 2, pp. 1117-1122, 1991.

[23] J. Heerden, M. M. Ehlers, and W. O. K. Grabow, "Detection and risk assessment of adenoviruses in swimming pool water," Journal of Applied Microbiology, vol. 99, no. 5, pp. 1256-1264, 2005.

[24] J. Heerden, M. M. Ehlers, A. Heim, and W. O. K. Grabow, "Prevalence, quantification and typing of adenoviruses detected in river and treated drinking water in South Africa," Journal of Applied Microbiology, vol. 99, no. 2, pp. 234-242, 2005.

[25] S. Bofill-Mas, N. Albinana-Gimenez, P. Clemente-Casares et al., "Quantification and stability of human adenoviruses and polyomavirus JCPyV in wastewater matrices," Applied and Environmental Microbiology, vol. 72, no. 12, pp. 78947896, 2006.

[26] J. A. Fuhrman, X. Liang, and R. T. Noble, "Rapid detection of enteroviruses in small volumes of natural waters by real-time quantitative reverse transcriptase PCR," Applied and Environmental Microbiology, vol. 71, no. 8, pp. 4523-4530, 2005.

[27] E. M. Symonds, D. W. Griffin, and M. Breitbart, "Eukaryotic viruses in wastewater samples from the United States," Applied and Environmental Microbiology, vol. 75, no. 5, pp. 1402-1409, 2009.

[28] E. Haramoto, M. Kitajima, A. Hata et al., "A review on recent progress in the detection methods and prevalence of human enteric viruses in water," Water Research, vol. 135, pp. 168186, 2018.

[29] G. Masachessi, M. B. Pisano, V. E. Prez et al., "Enteric viruses in surface waters from Argentina: molecular and viable-virus detection," Applied and Environmental Microbiology, vol. 84, no. 5, pp. 1-12, 2018.

[30] J. L. Cannon, G. W. Park, J. Osborne, L.-A. Jaykus, and J. Vinjé, "Surrogates for the study of norovirus stability and inactivation in the environment: a comparison of murine norovirus and feline calicivirus," Journal of Food Protection, vol. 69, no. 11, pp. 2761-2765, 2006.

[31] J. A. Papafragkou, M. E. Andersson, G. Vansarla et al., "Monitoring of seasonality of norovirus and other enteric viruses in Cameroon by real-time PCR: an exploratory study," Epidemiology and Infection, 2013.

[32] D. Fisman, "Seasonality of viral infections: mechanisms and unknowns," Clinical Microbiology and Infection, vol. 18, no. 10, pp. 946-954, 2012.

[33] K. E. Gibson, "Viral pathogens in water: occurrence, public health impact, and available control strategies," Current Opinion in Virology, vol. 4, pp. 50-57, 2014. 
[34] A. Allard, B. Albinsson, and G. Wadell, "Detection of adenoviruses in stools from healthy persons and patients with diarrhea by two-step polymerase chain reaction," Journal of Medical Virology, vol. 37, no. 2, pp. 149-157, 1992.

[35] UN-HABITAT, Strategic Urban Development Plan for Homa Bay Municipality (2008-2030), United Nations Human Settlement Programme (UN-HABITAT), Nairobi, Kenya, 2010.

[36] FAO and KFSSG, Crop, Livestock and Fisheries High Rainfall Areas Assessment 2012, KFSSG, Nairobi, Kenya, 2012.

[37] American Public Health Association, Standard Methods for the Examination of Water and Wastewater, American Public Health Association, Washington, DC, USA, 21st edition, 2005.

[38] N. M. Kiulia, R. Netshikweta, N. A. Page et al., "The detection of enteric viruses in selected urban and rural river water and sewage in Kenya, with special reference to rotaviruses," Journal of Applied Microbiology, vol. 109, no. 3, pp. 818-828, 2010.

[39] P. Vilaginès, B. Sarrette, G. Husson, and R. Vilaginès, "Glass wool for virus concentration at ambient water $\mathrm{pH}$ level," Water Science and Technology, vol. 27, no. 3-4, pp. 299-306, 1993.

[40] M. Wolfaardt, C. L. Moe, and W. O. K. Grabow, "Detection of small round structured viruses in clinical and environmental samples by polymerase chain reaction," Water Science and Technology, vol. 31, no. 5-6, pp. 375-382, 1995.

[41] E. Lambertini, S. K. Spencer, P. D. Bertz, F. J. Loge, B. A. Kieke, and M. A. Borchardt, "Concentration of enteroviruses, adenoviruses, and noroviruses from drinking water by use of glass wool filters," Applied and Environmental Microbiology, vol. 74, no. 10, pp. 2990-2996, 2008.

[42] M. P. Miagostovich, "Evaluation of an adsorption-elution method for detection of astrovirus and norovirus in environmental waters," Journal of Virological Methods, vol. 156, pp. 73-76, 2009.

[43] N. Kiulia, N. Hofstra, L. Vermeulen, M. Obara, G. Medema, and J. Rose, "Global occurrence and emission of rotaviruses to surface waters," Pathogens, vol. 4, no. 2, pp. 229-255, 2015.

[44] P. Vilaginès, A. Suarez, B. Sarrette, and R. Vilaginès, "Optimisation of the PEG reconcentration procedure for virus detection by cell culture or genomic amplification," Water Science and Technology, vol. 35, no. 11-12, pp. 455-459, 1997.

[45] H. B. Cho, S.-H. Lee, J.-C. Cho, and S.-J. Kim, "Detection of adenoviruses and enteroviruses in tap water and river water by reverse transcription multiplex PCR," Canadian Journal of Microbiology, vol. 46, no. 5, pp. 417-424, 2000.

[46] A. Allard, A. Kajon, and G. Wadell, "Simple procedure for discrimination and typing of enteric adenoviruses after detection by polymerase chain reaction," Journal of Medical Virology, vol. 44, no. 3, pp. 250-257, 1994.

[47] M. Puig, J. Jofre, F. Lucena, A. Allard, G. Wadell, and R. Girones, "Detection of adenoviruses and enteroviruses in polluted waters by nested PCR amplification," Applied and Environmental Microbiology, vol. 60, no. 8, pp. 2963-2970, 1994.

[48] A. Allard, R. Girones, P. Juto, and G. Wadell, "Polymerase chain reaction for detection of adenoviruses in stool samples," Journal of Clinical Microbiology, vol. 28, no. 12, pp. 26592667, 1990.

[49] F. M. Santos, M. J. Vieira, P. Garrafa et al., "Discrimination of adenovirus types circulating in urban sewage and surface polluted waters in São Paulo city, Brazil," Water Supply, vol. 4, no. 2, pp. 79-85, 2004.
[50] L. Kittigul, S. Ekchaloemkiet, F. Utrarachkij et al., "An efficient virus concentration method and RT-nested PCR for detection of rotaviruses in environmental water samples," Journal of Virological Methods, vol. 124, no. 1-2, pp. 117-122, 2005.

[51] V. Chigor and A. Okoh, "Quantitative RT-PCR detection of hepatitis A virus, rotaviruses and enteroviruses in the Buffalo River and source water dams in the Eastern Cape Province of South Africa," International Journal of Environmental Research and Public Health, vol. 9, no. 11, pp. 4017-4032, 2012.

[52] E. D'Ugo, S. Marcheggiani, I. Fioramonti et al., "Detection of enteric viruses in fresh water from European countries," Food Environmental Virology, vol. 8, pp. 206-2014, 2016.

[53] R. Staggemeier, T. M. S. Heck, M. Demoliner et al., "Enteric viruses and adenovirus diversity in waters from 2016 Olympic venues," Science of the Total Environment, vol. 586, pp. 304312, 2017.

[54] G. Fongaro, M. A. Nascimento, A. Viancelli, D. Tonetta, M. M. Petrucio, and C. R. M. Barardi, "Surveillance of human viral contamination and physicochemical profiles in a surface water lagoon," Water Science and Technology, vol. 66, no. 12, pp. 2682-2687, 2012.

[55] S. Choi and S. C. Jiang, "Real-time PCR quantification of human adenoviruses in urban rivers indicates genome prevalence but low infectivity," Applied and Environmental Microbiology, vol. 71, no. 11, pp. 7426-7433, 2005.

[56] J. P. S. Sidhu, L. Hodgers, W. Ahmed, M. N. Chong, and S. Toze, "Prevalence of human pathogens and indicators in stormwater runoff in Brisbane, Australia," Water Research, vol. 46, no. 20, pp. 6652-6660, 2012.

[57] K. Ulbricht, H.-C. Selinka, S. Wolter, K.-H. Rosenwinkel, and R. Nogueira, "A mass balance approach to the fate of viruses in a municipal wastewater treatment plant during summer and winter seasons," Water Science and Technology, vol. 69, no. 2, pp. 364-370, 2014.

[58] T. Y. Murray, J. Mans, and M. B. Taylor, "Human calicivirus diversity in wastewater in South Africa," Journal of Applied Microbiology, vol. 114, no. 6, pp. 1843-1853, 2013.

[59] H. Katayama, E. Haramoto, K. Oguma et al., "One-year monthly quantitative survey of noroviruses, enteroviruses, and adenoviruses in wastewater collected from six plants in Japan," Water Research, vol. 42, no. 6-7, pp. 1441-1448, 2008.

[60] S. R. Corsi, M. A. Borchardt, S. K. Spencer, P. E. Hughes, and A. K. Baldwin, "Human and bovine viruses in the Milwaukee River watershed: hydrologically relevant representation and relations with environmental variables," Science of The Total Environment, vol. 490, pp. 849-860, 2014.

[61] S. M. Dorner, W. B. Anderson, T. Gaulin et al., "Pathogen and indicator variability in a heavily impacted watershed," Journal of Water and Health, vol. 5, no. 2, pp. 241-257, 2007.

[62] T.-T. Fong and E. K. Lipp, "Enteric viruses of humans and animals in aquatic environments: health risks, detection, and potential water quality assessment tools," Microbiology and Molecular Biology Reviews, vol. 69, no. 2, pp. 357-371, 2005.

[63] I. Xagoraraki, D. H.-W. Kuo, K. Wong, M. Wong, and J. B. Rose, "Occurrence of human adenoviruses at two recreational beaches of the great lakes," Applied and Environmental Microbiology, vol. 73, no. 24, pp. 7874-7881, 2007.

[64] A. C. Espinosa, M. Mazari-Hiriart, R. Espinosa, L. MaruriAvidal, E. Méndez, and C. F. Arias, "Infectivity and genome persistence of rotavirus and astrovirus in groundwater and surface water," Water Research, vol. 42, no. 10-11, pp. 2618-2628, 2008. 
[65] E. K. Lipp, R. Kurz, R. Vincent, C. Rodriguez-Palacios, S. R. Farrah, and J. B. Rose, "The effects of seasonal variability and weather on microbial fecal pollution and enteric pathogens in a subtropical estuary," Estuaries, vol. 24, no. 2, pp. 266-276, 2001.

[66] I. G. Wilson, "Inhibition and facilitation of nucleic acid amplification," Applied and Environmental Microbiology, vol. 63, no. 10, pp. 3741-3751, 1997.

[67] T. M. Straub, I. L. Pepper, and C. P. Gerba, "Removal of PCR inhibiting substances in sewage sludge amended soil," Water Science and Technology, vol. 31, no. 5-6, pp. 311-315, 1995.

[68] WHO, Progress on Drinking-Water and Sanitation-2012 Update Launched on 6 March 2012, World Health Organization, Geneva, Switzerland, 2012.

[69] WHO, Guidelines for Drinking Water quality. Vol 1. Recommendations, World Health Organization, Geneva, Switzerland, 3rd edition, 2004.

[70] DFID, A Simple Methodology for Water Quality Monitoring, G. R.Pearcce, Chaundry, and S. Ghulum, Eds., Department for International Development, Wallingford, UK, 1999.

[71] K. Blume, J. Macedo, A. Meneguzzi, L. Silva, D. Quevedo, and M. Rodrigues, "Water quality assessment of the Sinos river, Southern Brazil," Brazilian Journal of Biology, vol. 70, no. 4, pp. 1185-1193, 2010.

[72] M. P. Miagostovich, F. R. Guimarães, C. B. Vieira et al., "Assessment of water quality in a border region between the Atlantic forest and an urbanised area in Rio de Janeiro, Brazil," Food and Environmental Virology, vol. 6, no. 2, pp. 110-115.

[73] C. B. Gaspar, A. C. D. O. Mendes, F. R. Guimarães et al., "Detection of enteric viruses in recreational waters of an urban lagoon in the city of Rio de Janeiro, Brazil," Memórias do Instituto Oswaldo Cruz, vol. 107, no. 6, pp. 778-784, 2012.

[74] G.-C. Lee, W.-H. Jheong, M.-J. Kim, D. H. Choi, and K.-H. Baik, "A 5-year survey (2007-2011) of enteric viruses in Korean aquatic environments and the use of coliforms as viral indicators," Microbiology and Immunology, vol. 57, no. 1, pp. 46-53, 2013. 